\title{
Development of a System for Decision Support in the Field of Ecological-Economic Security
}

\section{Tokarev Kirill Evgenievich}

\author{
Candidate of Economic Sciences, Associate Professor, Volgograd State Agricultural University
} Volgograd, 400002, Russia; E-mail: tke.vgsha@mail.ru

\section{Doi:10.5901/mjss.2015.v6n6s2p415}

\section{Abstract}

Studies in recent years have been directed in search of various methods for solving problems of management of ecologicaleconomic security on the basis of economic-mathematical models. However, the development of modern information technology has enabled the introduction of methods based on the data of ecological-economic systems, the use of specialized expert systems, and decision support to justify a wide range of tasks for planning, forecasting and management of ecologicaleconomic systems. Of particular relevance is the establishment of systems for decision support in environmental management. For the implementation of tasks of management of ecological and economic security of the used mathematical apparatus of multi-criteria hierarchical analysis and synthesis. The study revealed the specificity of the category of eco-economic system, the algorithm of hierarchical analysis and synthesis of its components, the developed diagram of functioning of system of support of making decisions and also carried out its program implementation is based on MySQL and a free environment for rapid application development IDE Lazarus. The structure of the software, based on mathematical apparatus of hierarchical analysis and synthesis of components, allowed to solve the problem of automation of procedures for evaluation, comparison, selection and evaluation of the quality of managerial decisions, based on hierarchical analysis and synthesis of indicative indicators of systems of ecological and economic security, in the field of environmental management.

Keywords: system for decision support, ecological-economic security, hierarchical analysis and synthesis

\section{Introduction}

According to the national security strategy of Russia until 2020, ecological and economic security is presented as a basic, essential element of national security, including external and internal factors, the vital interests of the security objects the individual, society, state, real and potential threats to their security, the institutions of the security agents.

Studies in recent years have been directed in search of various methods for solving problems of management of ecological-economic security on the basis of economic-mathematical models.

\section{Literature Review}

Studies in recent years have been directed in search of various methods for solving problems of management of ecological-economic security on the basis of economic-mathematical models. In particular, the issues of modeling the security of ecological-economic systems dedicated to the works of Mazaeva (2010), Kuzmin (2013), Rogachev (20092015), Natalia Skiter (2012), Fedorova (2014) and others.

However, in the studies analysed, not enough attention was paid to the development of systems of support of decision-making parameters of ecological and economic security by improving existing methods of hierarchical analysis and synthesis of semi-structured systems.

\section{Results and Discussion}

With the development of modern information technologies there appeared the possibility of introducing methods based on the data of ecological-economic systems, the use of specialized expert systems, and decision support to justify a wide range of tasks for planning, forecasting and management of ecological-economic systems. The establishment of systems for decision support in the management of environmental management, will lead to qualitatively new results in the provision of ecological and economic security of the country. Thus, research in the field of development of systems for decision support for security management of ecological-economic systems of particular relevance. 
For the implementation of tasks of management of ecological and economic security of the used mathematical apparatus of multi-criteria hierarchical analysis and synthesis. The main objective of hierarchical representation systems, including environmental management, is to assess higher levels based on the interaction of various levels of the hierarchy and not from direct dependence on the elements at these levels.

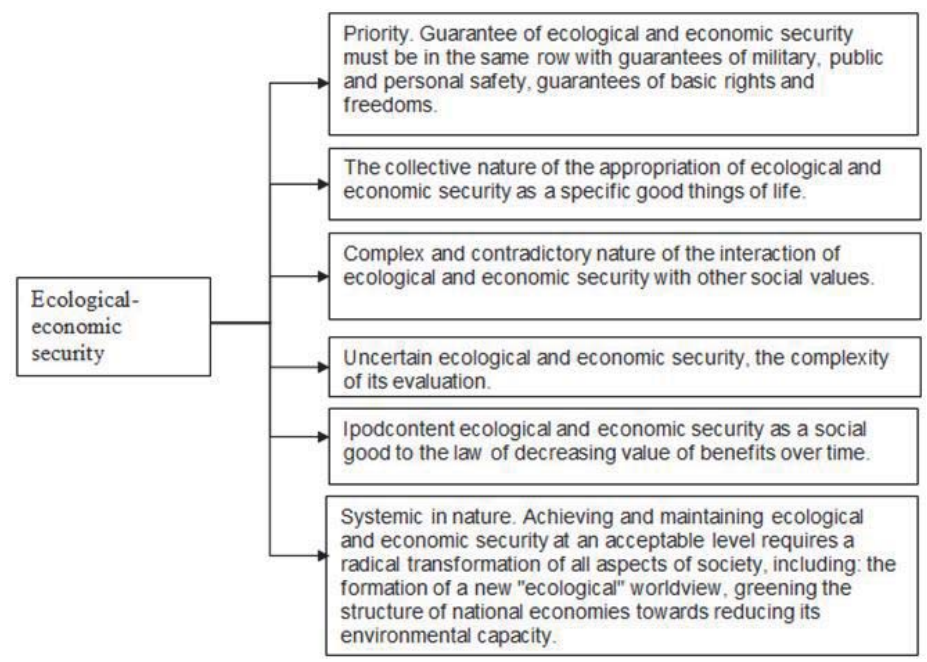

Figure 1 - Structure of the category "ecological-economic security"

At the initial stage of research was the analysis of the category "ecological and economic security", which allowed to select indicators for subsequent structuring, for qualitative and quantitative traits (Figure 1). Systems of support of decision making that are designed specifically to assist in problem solving locate, analyze and select the best possible option, should be considered as software and information and analytical technologies. The entity making the decision, shall be provided both information and technological support. Technology computer-aided analysis of ecologicaleconomic systems is a complex structure, requiring for its creation of a systematic approach. One of the most important principles of the system approach used in the creation of a DSS, is the principle of hierarchical decomposition and multicriteria analysis.

The specifics of the structure of the DSS in the field of ecological and economic security is to parallel the functioning of the information components at the following levels:

- system level (building a model of the object);

- cybernetic (designing governance arrangements);

- operating (system description at the level of technological processes and patterns in a formalized and verbal language);

- algorithmic (development of algorithms for solving problems);

- information (design information model of the object); program (project implementation).

In the process of analysis of the category "safety ecological-economic systems" have been identified and systematized indicators that will take into account the entire spectrum of endogenous and exogenous factors for the synthesis and hierarchical analysis of threats (Table 1).

Table 1 - Classification of threats to ecological and economic security

\begin{tabular}{|c|c|c|}
\hline The classification criterion & Type of threat & Indicative symptom \\
\hline The object of influence & $\begin{array}{l}\text { - Human resources, } \\
\text { - Material, } \\
\text { - Financial, Information, } \\
\text { - Technology. }\end{array}$ & \multirow{2}{*}{$\begin{array}{l}\text { - Stagnation of production; } \\
\text { Corruption; } \\
\text { Ineffective monetary and customs policy of the state; } \\
\text { Structural deformirovannoi industry; } \\
\text { High depreciation of fixed assets; }\end{array}$} \\
\hline The subject of the impact & - crlminal structures; & \\
\hline
\end{tabular}




\begin{tabular}{|c|c|c|}
\hline & $\begin{array}{l}\text { - Unfair competitors; } \\
\text { Counterparty; The staff. }\end{array}$ & \multirow{7}{*}{$\begin{array}{l}\text { Criminalization of corporate relations; } \\
\text { Weak use of natural resources potential; } \\
\text { Low technical and technological level of production; } \\
\text { - } \quad \text { Low level of innovation activity; } \\
\text { Dependence on imported equipment and technologies; } \\
\text { - } \quad \text { The inefficiency of the stock market in terms of attracting } \\
\text { investment; } \\
\text { The lack of real protectionist policy of the state in relation } \\
\text { to domestic producers; } \\
\text { Changes in tax legislation; } \\
\text { Low credit and banking support to the real sector; } \\
\text { - Low qualification of specialists; } \\
\text { Inefficient work of the Department of economic security; } \\
\text { The underdevelopment of the means and methods to } \\
\text { protect their own economic security; } \\
\text { Growth rates for energy and transport; } \\
\text { The deteriorating situation on the world markets; } \\
\text { Discriminatory measures to the Russian goods on the } \\
\text { world markets; } \\
\text { Low solvent demand on the domestic market; } \\
\text { Increased competition; } \\
\text { Low competitiveness of products. }\end{array}$} \\
\hline $\begin{array}{l}\text { The possibility of damage } \\
\text { assessment }\end{array}$ & $\begin{array}{l}\text { - } \quad \text { Quantitative assessment, } \\
\text { - } \text { Qualitative assessment. }\end{array}$ & \\
\hline Location & $\begin{array}{ll}- & \text { External (industry, country, world), } \\
\text { - } & \text { Domestic. }\end{array}$ & \\
\hline The ability to eliminate & $\begin{array}{l}-\quad \text { Subject to elimination, } \\
\text { - } \\
\text { Not subject to elimination. }\end{array}$ & \\
\hline $\begin{array}{l}\text { On the severity of the } \\
\text { consequences }\end{array}$ & $\begin{array}{ll}- & \text { High, } \\
- & \text { Significant, } \\
- & \text { Medium, } \\
- & \text { Low severity of consequences. }\end{array}$ & \\
\hline $\begin{array}{l}\text { According to the degree of } \\
\text { probability }\end{array}$ & $\begin{array}{ll}- & \text { Unlikely } \\
- & \text { Real. } \\
\end{array}$ & \\
\hline $\begin{array}{l}\text { Stage of activity of the } \\
\text { enterprise }\end{array}$ & $\begin{array}{l}\text { - } \text { At the stage of creation of the } \\
\text { enterprise, } \\
-\quad \text { At the stage of functioning. }\end{array}$ & \\
\hline
\end{tabular}

The procedure of decision making in the field of safety management of ecological-economic systems based on multicriteria analysis and synthesis are presented in figure 2 .

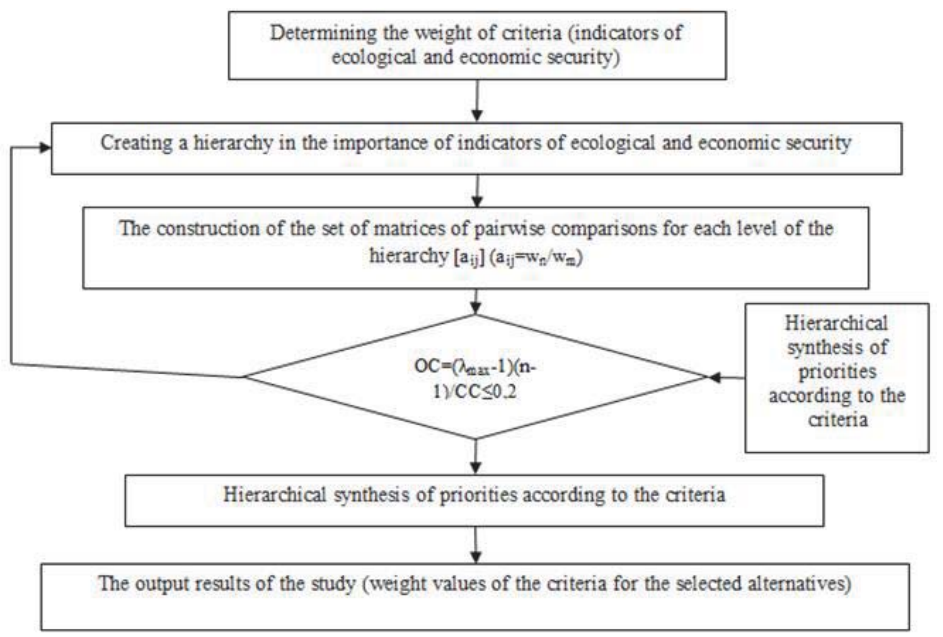

Figure 2 - Hierarchical algorithm of analysis and synthesis in the field of environmental economic management

The main objective of hierarchical representation of the system is the highest rating levels based on the interaction of various levels of the hierarchy and not from direct dependence on the elements at these levels. Exact methods for constructing systems in hierarchies gradually appear in the natural and social Sciences, and especially in problems of General systems theory related to the planning and building of social systems. Conceptually, the simplest hierarchy is linear, rising from one level of elements to the adjacent level. In the nonlinear hierarchy upper level can be in a dominant position in relation to the lower level and dominated. In the mathematical theory of hierarchy analysis method is developed the methodology for the assessment of exposure level to its adjacent upper level by means of the composition of the relevant contribution (priorities) of elements of a lower level relative to the top-level element. This composition may spread up the component hierarchy.

The first step towards building the hierarchy is the outlining of the research problem. Then building a hierarchical 
model that includes the focus of the hierarchy (goal), located in its top, intermediate levels (criteria evaluation system) and preferred alternatives that form the lowest hierarchical level. Analytic hierarchy allows you to group elements of the system support decision making in the field of ecological and economic security, namely actors (decision makers, experts), criteria, alternatives and global factors in the hierarchical model (Figure 3).

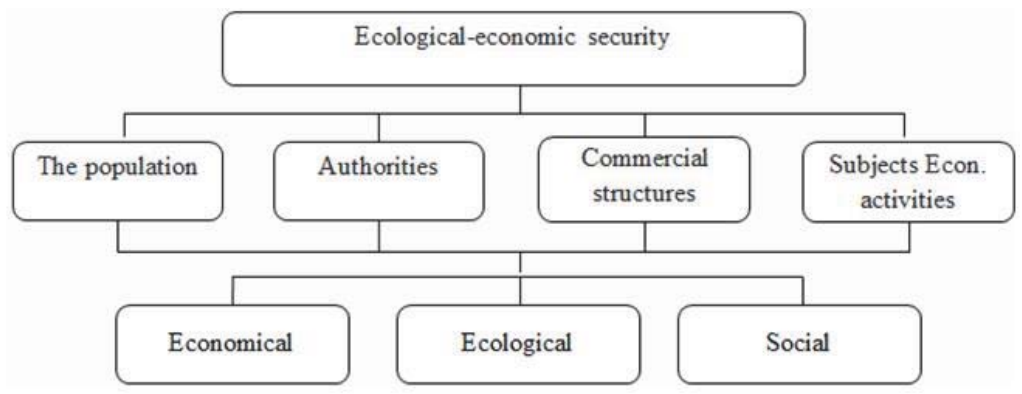

Figure 3 - Hierarchy of the level of importance of threats to ecological-economic security

The proposed multi-criteria hierarchical model assessing the importance of threats to ecological and economic security enables you to correlate the impact of changes in priorities of the upper levels on the priorities of the lower levels that will allow to get more detailed information about the structural and functional condition of the system by the gradual structuring and synthesis of its modules.

To automate the procedure of decision support in the field of ecological and economic security based on multicriteria hierarchical analysis and synthesis in the integrated application development environment IDE Lazarus implemented a software module and database storage objects and descriptions based on MySQL.

The main functions of the developed program:

- storage of objects and descriptions in a database;

- enter and edit the parameters of the hierarchy;

- hierarchical analysis and synthesis of indicative indicators;

- multicriteria estimation of the parameters of the ecological-economic system;

- export results in a format *.html and print output.

\section{Conclusions}

The study developed component architecture and structure of functioning of system of support of decision-making in the sphere of ecological and economic security, carried out the software implementation of a relational database to store objects and descriptions of the system and also the instrumental environment support.

Thus, the use of DSS can solve the problem of automation of procedures for the selection, comparison and evaluation of the quality of managerial decisions in the sphere of ecological and economic security through stricter accounting and reconciling the opinions of experts within the proposed hierarchy.

\section{References}

Kuzmin V. A., Tokarev K. E. Assessment of threats to economic security method for hierarchical synthesis // Modern problems of science and education. - 2013. - No. 2; URL: www.science-education.ru/108-8787.

Kuzmin V. A., K. E. Tokarev Implementation of algorithm for economic security on the basis of fuzzy-set approach in MatLab // Modern scientific research and innovation. 2012. No. 7 [Electronic resource]. URL: http://web.snauka.ru/issues/2012/07/15773.

Mazaeva T. I. Mathematical modeling and analysis of the processes of technological innovation in the context of economic security I Mazaeva T. I., Rogachev A. F. // Economics and entrepreneurship. 2012. No. 5 (28). P. 296-298.

Rogachev A. F. Mathematical software system to support decision making on the basis of GIS-technologies // Proceedings of the lower Volga agrodiversity complex: Science and higher education. 2009. No. 2. P. 144-151.

Rogachev A. F. Methodological approaches to the modeling of ecological and economic security // Economics and entrepreneurship. 2013. No. 12-4 (41-4). P. 107-109.

Rogachev A. F. Optimization of innovative design solutions in the food sector // proceedings of the lower Volga agrodiversity complex: 
Science and higher education. 2015. №. 1 (37). P. 223-228.

Rogachev A. F. Fuzzy modeling of ecological-economic systems / Rogachev A. F., Fedorov, Y. V. //Modern problems of science and education. 2014. No. 5. S. 317.

Shatyrko D., Tokarev K. E., Kuzmin V. A. Modeling regional economic development apk using tools of fuzzy logic conclusion /I Fundamental research . - $2015-$ No. 7 (part 1), p. 217-221.

Tokarev K. E., Kuzmin V. A., Shatyrko D.V., Development of the decision support system tools in the field of ecological and economic security // Modern Economics: Problems and Solutions - 2015. - No.5, p. 31-41.( DOI: 10.17308/meps.2015.5/1215).

Tokarev K. E., Rogachev A. F. Information support for decision making in multi-criteria evaluation of quality of services // Modern problems of science and education. - 2012. - No. 2; URL: www.science-education.ru/102-5578.

Tokarev, K. E., Shatyrko D.V., M. P. Protsyk Cognitive modeling regional food security APK // Modern scientific research and innovation. 2014. No. 10 [Electronic resource]. URL: http://web.snauka.ru/issues/2014/10/38352.

Natalia Skiter, Aleksey F. Rogachev, Tamara I. Mazaeva. Modeling Ecological Security of a State // Mediterian Journal of Social Science. Vol. 6 No. 3 S. 6 June 2015. p. 185-192. 